\title{
A comparative assessment of water use efficiency in groundnut (Arachis hypogaea) grown in containers and in the field under water-limited conditions
}

\author{
K. B. HEBBAR ${ }^{1 *}$, V. R. SASHIDHAR ${ }^{2}$, M. UDAYAKUMAR ${ }^{1}$, R. DEVENDRA ${ }^{1}$ \\ AND R. C. NAGESWARA RAO" \\ ${ }^{1}$ Department of Crop Physiology, University of Agricultural Sciences, GKVK Campus, \\ Bangalore 560065 , India \\ ${ }^{2}$ International Crop Research Institute for the Semi-Arid Tropics (ICRISAT), Patamcheru, PO 502324, \\ Andhra Pradesh, India
}

(Revised its received 6 Scptember 1993)

\begin{abstract}
SUMMARY
Water use efficiency (WUE) was measured on fourteen genotypes of groundnut (Arachis hypogaea L.) grown in containers under adequately irrigated and vater-limited conditions. The genotypes used similar amounts of water but produced different quantities of dry matter. WUE accounted for $>92 \%$ of the variation in dry matter production under both irrigated and water-limited conditions. There was a significant increase in WUE under water-limited conditions. Four genotypes selected from the container experiment as having either a high or a low WUE under non-limited or limited water input conditions were further tested under prolonged water deficit conditions in a field experiment. WUE varied significantly between genotypes and there was a positive correlation between WUE and the quantity of dry matter produced by the genotypes. The results suggested that, in three out of four genotypes, the WUE measured in the container experiment was positively correlated with the WUE estimated under field conditions.
\end{abstract}

\section{INTRODUCTION}

Groundnut is an important oilseed and cash crop grown mainly under rainfed conditions in the semiarid regions of the world. About $67 \%$ of the world's groundnut production comes from rainfed cultivation (Gibbons 1980). Hence, any trait or practice which can improve groundnut production under rainfed cultivation is of immediate importance to semi-arid farmers.

Dry matter (DM) production is a product of $T \times$ WUE (Briggs \& Shantz 1914; de Wit 1958) where $T$ is the amount of water transpired and WUE is the water use efficiency, defined as the quantity of DM produced per unit of water transpired. Thus, it is apparent that WUE is onc of the most important factors influencing crop productivity, particularly under water-limited conditions (Turner 1986; Uma 1987; Martin \& Thorstenson 1988). Significant genotypic variations in WUE between different

* Present address: Water Technology Centre, Indian Agricultural Research Institute, New Delhi 110012 , India.

$\dagger$ To whom correspondence should be addressed. groundnut genotypes have bcen reported (Hubick et al. 1986; Wright et al. 1988; Nageswara Rao et al. 1993).

WUE measurements may be made at three levels: (i) in single leaves using gas exchange techniques; (ii) in whole plants grown in containers; and (iii) at the canopy level based on evapotranspiration in the field (Fischer \& Turner 1978). Although uscful, WUE is difficult to measure in the field because of the lack of suitable techniques for measuring accurately the root mass and water use of plants (Martin \& Thorstenson 1988). Recent studies have shown that carbon isotope discrimination occurring during carbon assimilation by leaves is closely related to WUE in various crops (Farquhar \& Richards 1984; Hubick et al. 1986; Farquhar et al. 1989), suggesting that carbon isotope discrimination technology can be used to screen genotypes for WUE. However, measurement of carbon isotope composition requires expensive instrumentation and specific expertise. Thus, the use of carbon isotope methodology to screen genotypes for WUE may be limited in developing countries in the near future.

Expcriments involving the use of containers to 
study whole plant WUE date back to the 19tl century (Briggs \& Shantz 1913, 1914). Despite the inevitable drawbacks of container studies, this approach has been adopted widely in more recent studies of WUE (Hubick \& Farquhar 1987; Wright et al. 1988, 1994). The use of containers in WUE studics has been further supported by the observation that the ranking of species (particularly between $C_{3}$ and $C_{4}$ ) at the whole plant level showed a close relationship with WUE determined at the single leaf level from gas exchange measurements (Downes 1969; Ravishankar 1988), and that the ranking of species for WUE is remarkably consistent across seasons (Jones 1983).

Limited attempts have been made to compare the relative ranking of WUE in genotypes within a species grown in containers with those grown in the field under both non-limiting and water-limited input conditions (Tcare el al. 1973; Shashikumar 1983). If WUE has to be considered and used ats a trait in crop improvement programmes, such attempts are imperative. In the present study, experinents were therefore conducted to: (i) examine genotypic variability in WUE over a range of groundnut genotypes under non-limited and water-limited conditions; (ii) assess the relationship between the ranking of WUE of genotypes measured under both non-limiting and water-limitcd input conditions in container studies with that measured under field conditions; and (iii) cxaminc the relevance of WUE as a drought resistance trait under water-limited conditions in the field.

\section{MATERIALS AND METHODS}

\section{Experiment /}

A container experiment was conducted during the rainy season (July-October) 1988 in a glasshouse at the University of Agricultural Sciences, Bangalore, in south India. Fourteen groundnut (Arachis hypogaea L.) genotypes bclonging to the varietics vulgaris (spanish) and fastigiata (valencia) were used to assess differences in WUE. Plants were grown in containers made of carbonized rubber $28 \mathrm{~cm}$ long, $14.4 \mathrm{~cm}$ wide and $12.5 \mathrm{~cm}$ decp, containing $8 \mathrm{~kg}$ of red loamy soil. Basal fertilizer (18 N:40 P:0 K/ha) was mixed into the topsoil at sowing. Each genotype was planted in ten containers and two plants were grown in each containcr. Plants were watered daily until 30 days after sowing (DAS), when two irrigation regimes were imposed.

At 30 DAS, all containers were saturated with water and any excess was allowed to drain through a drainage hole in the base of the container. When water leakage stopped, the drainage holes were blocked to prevent any further seepage of water from the containers. The exposed soil surface was covered with pieces of polythene to minimize soil evaporation. The containers wcre arranged in a split-plot design with two irrigation regimes $\left(I_{1}\right.$ and $\left.I_{2}\right)$ as the main treatments and the fourteen genotypes as subtreatments. There were five container replicates for each main treatment.

Treatment $I_{1}$ received adequate water to maintain the soil at its field capacity of $15.5 \%$ moisture (noted from initial soil moisture measurcments). The plants in treatment $I_{2}$ received $60 \%$ of the water given to the plants in $I_{1}$. The amount of water loss was determined by weighing the containers daily using a Bench Platform Balance $(20 \mathrm{~kg}$ capacity with a resolution of $20 \mathrm{~g}$ ). Two or three containers with soil and plastic mulch, but without plants, were maintained in each treatment to monitor soil evaporation in the absence of plants.

The experiment was terminated at 62 DAS. The shoots were harvested along with the roots, and the dry weight of the whole plant (including roots) was determined after oven-drying at $70^{\circ} \mathrm{C}$ for $48 \mathrm{~h}$.

Tolat dry matter (DM) accumulation including roots during the experimental period was computed as the increase in DM/plant between 30 and 62 DAS.

Transpiration ( $\mathrm{T}$ ) during the experimental period was estimated as $\mathrm{T}=I-\left(E s+U_{w}\right)$ where $I$ is the cumulative water added during the treatment period, $E s$ is soil evaporation, and $U_{w}$ the unused water left in the container at the end of the treatment period. Es was estimated from the water loss from the empty containers in the absence of plants. Water usc efficiency $(\mathrm{g} / \mathrm{kg})$ was estimated as the ratio of $\mathrm{DM}$ produced between 30-62 DAS to transpiration (T) during the same period.

\section{Experiment 2}

Four genotypes were selected on the basis of their differing WUE responses under both non-limited (treatment $I_{1}$ ) and water-limited (treatment $I_{2}$ ) input conditions in Expt 1, as follows:

1. Genotype ICGV86843 (Low WUE in $I_{1}$, Low WUE in $I_{2}$ ),

2. Genotype ICGV87160 (High WUE in $I_{1}$, Low WUE in $I_{2}$ ),

3. Genotype ICGV86315 (Low WUE in $I_{1}$, High WUE in $\mathrm{I}_{2}$ ),

4. Genotype TMV2 (High WUE in $I_{1}$, High WUE in $\mathrm{I}_{2}$ ).

The field experiment was conducted on a red loamy soil, during the summer season (February-May) 1989 at the University of Agricultural Sciences experimental farm, Bangalore. The field was disc-ploughed and a basal fertilizer containing $18 \mathrm{~N}: 46 \mathrm{P}$ was incorporated into the soil at land preparation. The experiment was laid out as a split-plot design with two irrigation treatments $\left(I_{1}\right.$ and $\left.I_{n}\right)$ as the main plots and the four genotypes as subplots. There were three replications. Seeds of each genotype were hand-sown on 5 February 1989 in ten rows each $4 \mathrm{~m}$ in length, 
Table 1. Total dry matter $(D M)(\mathrm{g} /$ plant), transpiration $(T)(\mathrm{kg} / \mathrm{plant})$ and water use efficiency (WUE) of fourteen groundmut genotypes grown in containers under irrigated $\left(I_{1}\right)$ and water-limited $\left(I_{2}\right)$ conditions between 30 and 62 DAS

\begin{tabular}{|c|c|c|c|c|}
\hline Genotype & Treatment & $\begin{array}{c}\text { DM } \\
\text { (g) }\end{array}$ & $\underset{(\mathrm{kg})}{\mathrm{T}}$ & $\begin{array}{l}\text { WUE } \\
(\mathrm{g} / \mathrm{kg})\end{array}$ \\
\hline ICGV87160 & $\begin{array}{l}! \\
2\end{array}$ & $\begin{array}{r}13.5 \\
8.3\end{array}$ & $\begin{array}{l}6.0 \\
3.4\end{array}$ & $\begin{array}{l}2 \cdot 3 \\
2 \cdot 4\end{array}$ \\
\hline ICGV86031 & $\begin{array}{l}1 \\
2\end{array}$ & $\begin{array}{l}15.2 \\
10.7\end{array}$ & $\begin{array}{l}6.0 \\
3.4\end{array}$ & $\begin{array}{l}2 \cdot 5 \\
3 \cdot 2\end{array}$ \\
\hline TMV2 & $\begin{array}{l}1 \\
2\end{array}$ & $\begin{array}{l}14.8 \\
10.2\end{array}$ & $\begin{array}{l}5 \cdot 8 \\
3 \cdot 4\end{array}$ & $\begin{array}{l}2 \cdot 4 \\
2 \cdot 9\end{array}$ \\
\hline $\mathrm{DH}+3-30$ & $\begin{array}{l}1 \\
2\end{array}$ & $\begin{array}{l}14 \cdot 7 \\
10 \cdot 2\end{array}$ & $\begin{array}{l}6.0 \\
3.4\end{array}$ & $\begin{array}{l}2 \cdot 3 \\
2 \cdot 7\end{array}$ \\
\hline ICGSII & $\begin{array}{l}1 \\
2\end{array}$ & $\begin{array}{r}10.4 \\
8.5\end{array}$ & $\begin{array}{l}5 \cdot 8 \\
3 \cdot 4\end{array}$ & $\begin{array}{l}1.5 \\
2.5\end{array}$ \\
\hline ICGV86124 & $\begin{array}{l}1 \\
2\end{array}$ & $\begin{array}{r}16.5 \\
9.9\end{array}$ & $\begin{array}{l}5.8 \\
3.4\end{array}$ & $\begin{array}{l}2.7 \\
3.0\end{array}$ \\
\hline ICGV\$6234 & $\begin{array}{l}1 \\
2\end{array}$ & $\begin{array}{r}10.5 \\
7.4\end{array}$ & $\begin{array}{l}5 \cdot 8 \\
3 \cdot 4\end{array}$ & $\begin{array}{l}1 \cdot 7 \\
2 \cdot 2\end{array}$ \\
\hline ICGV86843 & $\begin{array}{l}1 \\
2\end{array}$ & $\begin{array}{l}6 \cdot 7 \\
5 \cdot 3\end{array}$ & $\begin{array}{l}5 \cdot 8 \\
3 \cdot 4\end{array}$ & $\begin{array}{l}1.2 \\
1.6\end{array}$ \\
\hline ICGV86832 & $\begin{array}{l}1 \\
2\end{array}$ & $\begin{array}{r}10 \cdot 3 \\
9.2\end{array}$ & $\begin{array}{l}5 \cdot 7 \\
3 \cdot 4\end{array}$ & $\begin{array}{l}1 \cdot 7 \\
2 \cdot 6\end{array}$ \\
\hline ICGV86552 & $\begin{array}{l}1 \\
2\end{array}$ & $\begin{array}{r}10.5 \\
8.7\end{array}$ & $\begin{array}{l}5 \cdot 5 \\
3 \cdot 3\end{array}$ & $\begin{array}{l}1.9 \\
2.8\end{array}$ \\
\hline 1CGV86187 & $\begin{array}{l}1 \\
2\end{array}$ & $\begin{array}{l}12 \cdot 3 \\
11 \cdot 3\end{array}$ & $\begin{array}{l}5 \cdot 7 \\
3 \cdot 3\end{array}$ & $\begin{array}{l}2 \cdot 2 \\
3 \cdot 5\end{array}$ \\
\hline ICGV86315 & $\begin{array}{l}1 \\
2\end{array}$ & $\begin{array}{r}11.1 \\
9.8\end{array}$ & $\begin{array}{l}5 \cdot 8 \\
3 \cdot 3\end{array}$ & $\begin{array}{l}2 \cdot 0 \\
3 \cdot 2\end{array}$ \\
\hline $1 C G V 86854$ & $\begin{array}{l}1 \\
2\end{array}$ & $\begin{array}{l}11 \cdot 7 \\
10.5\end{array}$ & $\begin{array}{l}5 \cdot 8 \\
3 \cdot 3\end{array}$ & $\begin{array}{l}2 \cdot 1 \\
3 \cdot 3\end{array}$ \\
\hline GNP214 & 1 & $\begin{array}{r}10.5 \\
9.6\end{array}$ & $\begin{array}{l}5.7 \\
3.3\end{array}$ & $\begin{array}{l}1.5 \\
2.9\end{array}$ \\
\hline $\begin{array}{l}\text { S.E. (for genotypes) } \\
\text { S.E. (for treatments) } \\
\text { S.E. (G } \times \text { T interaction) }\end{array}$ & & $\begin{array}{l}0.96 \\
0.28 \\
1.36\end{array}$ & $=$ & $\begin{array}{l}0.07 \\
0.03 \\
0.09\end{array}$ \\
\hline
\end{tabular}

with a spacing of $30 \mathrm{~cm}$ between rows and $15 \mathrm{~cm}$ between plants within rows. The crops were maintained free from pests and weeds by using appropriate plant protection measures as necessary.

All plots received adequate irrigation at 7-day intervals until 44 DAS, after which the two irrigation treatments $\left(I_{1}\right.$ and $\left.I_{2}\right)$ were imposed by applying measured quantities of water until 90 DAS. Treatment $\mathrm{I}$ was supplied with sufficient water to maintain the soil at field capacity (15.5\% soil moisture), while treatment $I_{2}$ received $60 \%$ of the water applied to $I_{1}$. The quantity of water required to maintain the plots at field capacity was estimated using the model of Ritchie (1973). This model was used to estimate evapotranspiration (ET) and transpiration (T) using soil, crop, irrigation and environmental characteristics. At $90 \mathrm{DAS}$, the plants from a $1 \mathrm{~m}^{2}$ area were harvested and the roots were separated. The shoots (vegetative + pods) were oven-dried at $80^{\circ} \mathrm{C}$ for $48 \mathrm{~h}$ before determining their dry weights.

WUE $(\mathrm{g} / \mathrm{kg})$ was calculated from the biomass (shoots + pods) produced during the treatment period (44-90 DAS) and transpiration (T) during the same period.

\section{RESULTS \\ Experiment 1}

The fourteen genotypes used similar quantities of water $\left(5.5-6.0 \mathrm{~kg}\right.$ in treatment $I_{1}$ and $3.3-3.4 \mathrm{~kg}$ in $I_{2}$ ) but were significantly different in DM production, which ranged from 6.7 to $16.5 \mathrm{~g} /$ plant in $\mathrm{I}_{1}$ and 5.3 to $11.3 \mathrm{~g} /$ plant in $l_{2}$ during the treatment period, resulting in a significant yariability in WUE between 


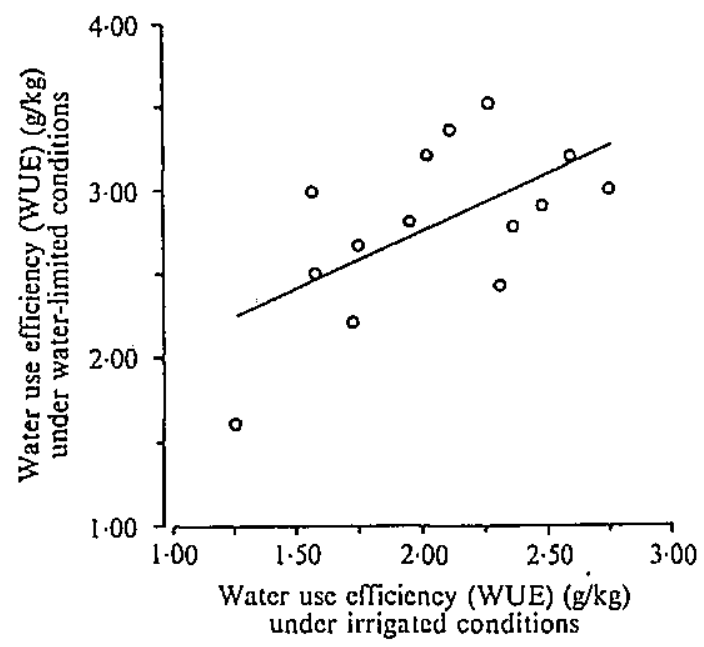

Fig. 1. Relationship between WUE values under irrigated and water-limited conditions in fourteen groundnut genotypes $(r=0.79, P<0.05)$ in a container experiment.

Table 2. Dry matter produced $(D M)\left(\mathrm{g} / \mathrm{m}^{2}\right)$, transpiration $(T)\left(\mathrm{kg} / \mathrm{m}^{2}\right)$, and water use efficiency (WUE) of four groumdint genotypes grown under irrigated $\left(I_{1}\right)$ and ivater-limited $\left(I_{2}\right)$ conditions between 44 and 96 $D A S$ in the field.

\begin{tabular}{lcccc}
\hline \hline Genotype & Treatment & $\begin{array}{c}\text { DM } \\
(\mathrm{g})\end{array}$ & $\begin{array}{c}\mathrm{T} \\
(\mathrm{kg})\end{array}$ & $\begin{array}{c}\text { WUE } \\
(\mathrm{g} / \mathrm{kg})\end{array}$ \\
\hline ICGV86315 & 1 & 253 & 139.5 & 1.8 \\
& 2 & 2.43 & 61.7 & 3.4 \\
ICGV87160 & 1 & 434 & 157.2 & 2.8 \\
& 2 & 198 & 63.5 & 3.1 \\
& & & & \\
TMV2 & 1 & 416 & 139.4 & 2.9 \\
& 2 & 254 & 67.8 & 3.8 \\
& & & & \\
ICGV86843 & 1 & 422 & 148.2 & 2.9 \\
& 2 & 319 & 73.4 & 4.3 \\
& & 9.18 & - & 0.09 \\
S.E. (for genotypes) & & 1.52 & - & 0.01 \\
S.E. (for trentments) & & 12.98 & - & 0.14 \\
S.E. (G $\times$ T interaction) & & & & \\
\hline \hline
\end{tabular}

genotypes $\left(1.2-2.7 \mathrm{~g} / \mathrm{kg}\right.$ in $I_{1}$ and $1.6-3.5 \mathrm{~g} / \mathrm{kg}$ in $\left.I_{2}\right)$ (Table 1). Genotype ICGV86124 had the highest WUE in treatment $l_{1}(2.7 \mathrm{~g} / \mathrm{kg})$, but ICGV86187 had the highest WUE $(3.5 \mathrm{~g} / \mathrm{kg})$ under water-limited conditions $\left(I_{2}\right)$. Genotype ICGV86843 had the lowest WUE in both irrigation treatments. Regression analysis between WUE and DM showed that c. $92 \%$ of the variation in DM production was accounted for by the variation in WUE, suggesting the importance

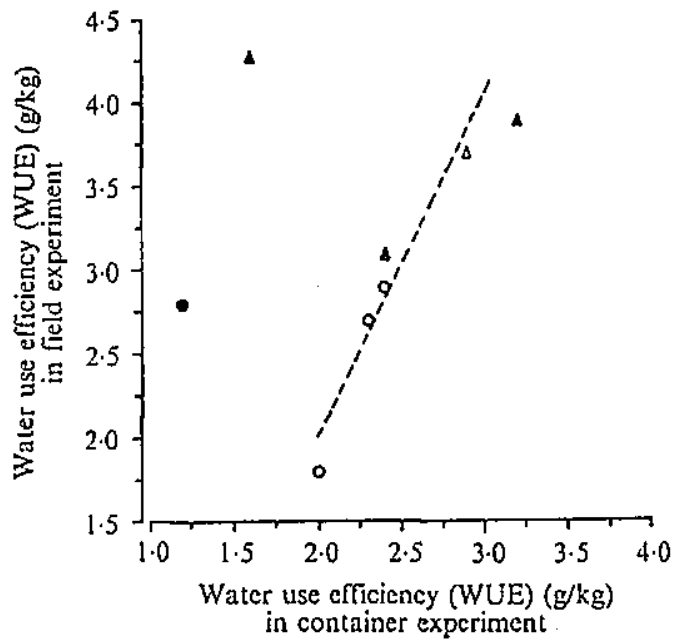

Fig. 2. Relationslip between WUE measured in the container experiment and in the field in four groundnut genotypes grown under irrigated $(O)$ and water-limited $(\Delta)$ conditions. - A represent genotype ICGV86843 (regression line fitted excluding ICGV86843; $r=0.96, P<0.01)$.

of WUE in determining crop productivity. WUE generally increased under water-limited conditions in all genotypes, although there was a positive correlation $(r=0.79, P<0.05)$ between WUE valucs recorded for treatments $I_{1}$ and $I_{2}$ (Fig. 1).

Based on deviation from the mean WUE under non-limited and limited water conditions, the genotypes could be grouped as follows:

1. Low WUE in both $I_{1}$ and $I_{2}$ : ICGV86843, ICGV86234 and ICGSII,

2. High WUE in $I_{1}$ and low WUE under $I_{2}$ : ICGV87160,

3. Low WUE in $I_{1}$ and high WUE under $I_{2}$ : ICGV86315, GNP214, ICGV86832 and ICGV86552, 4. High WUE in both $I_{1}$ and $I_{2}$ : TMV2, ICGV8603I, ICGV86187, ICGV86124, ICGV86854 and DH3-30.

\section{Experiment 2}

In the field experiment, the water use of the four selected genotypes in $I_{1}$ ranged from 139 to $157 \mathrm{~kg}$ during the experimental period, while DM production ranged from 253 to $434 \mathrm{~g} / \mathrm{m}^{2}$. In $\mathrm{I}_{\mathrm{n}}$, water use was $61-73 \mathrm{~kg}$ and DM production was $198-319 \mathrm{~g} / \mathrm{m}^{2}$ (Table 2). WUE for the four genotypes was $1.8-$ $2.9 \mathrm{~g} / \mathrm{kg}$ in $\mathrm{I}_{\mathrm{i}}$ and $3 \cdot 1-4.3 \mathrm{~g} / \mathrm{kg}$ in $\mathrm{I}_{2}$, representing a significant variation between genotypes. TMY2 and ICGV86843 gave the highest WUE values in treatments $\mathrm{I}_{1}$ and $\mathrm{I}_{2}$ respectively.

As in Expt 1 , there was an increase in WUE in all genotypes under water-limited conditions, although the extent of this increase varied between genotypes.

There was a significant positive correlation $(r=$ 
$0.96, P<0.01$ ) between the WUE values measured in the container and field experiments for three of the four genotypes (Fig. 2). The exception was ICGV86843, which had the lowest WUE in Expt 1 but a high WUE in Expt 2. Except for this discrepancy, the results suggest that the rclative ranking of genotypes for WUE in both experiments and treatments was consistent and that container experiments can be used effectively to alssess relative variations in WUE between groundnut genotypes.

\section{DISCUSSION}

In Expt 1, WUE in the fourteen genotypes used varied from 1.2 to $2.7 \mathrm{~g} / \mathrm{kg}$ under irrigated and from 1.6 to $3.5 \mathrm{~g} / \mathrm{kg}$ under water deficit conditions. Theso values are in accordance with the WUE range reported for $C_{\text {a }}$ crops such as groundnut (Hubick et al. 1986; Wright el (al. 1988, 1994). The physiological basis for vatrialtions in WUI between genolypes is not elear, although indireet evidenee from the present study and carlier work (Hubick ot al. 1986) suggests that, in groundnut, variation in photosynthetic capacity per unit leaf area might be a factor calusing variation in WUE. The increase in WUE observed in all genotypes under deficit conditions (Fig. 1) suggests an intrinsic ability of groundnut plants to adapt to drought conditions. Changes in the WUE of groundnut genotypes across a range of water regimes have been reported previously (Wright et al. 1988), but the physiological mechanisms responsible for such an increase in WUE under drought are not clear and this aspect requires further research. Although the positive correlation between the WUE values in treatments $I_{1}$ and $I_{2}$ seemed to suggest that selection for WUE could be made under either irrigation regime provided that the water status was maintained constant across genotypes, such a positive correlation between the WUE values for treatments $I_{I}$ and $I_{2}$ was not scen in Expt 2.
The WUE values observed in Expt 2 were generally greater than those in Expt 1. Variations in environmental factors between the glasshouse and the field might have contributed to variation in WUE between the experiments. Several environmental parameters; for example, vapour pressure deficit, temperature and irradiance, have been shown to influence water use efficiency (Tanner \& Sinclair 1983). Furthermore, in Expt 2 transpiration was computed using a simple soil water balance model (Ritchie 1973) and the cstimates of water use efficiency did not include root biomass. Genotypic variations in root mass, and root:shoot ratios have been reported for groundnut (Ketring 1984). Thus, it is possible that the estimated WUE values in Expt 2 might be confounded by an inability of the model to predict $T$ accurately and/or by genotypic variations in root:shoot ratios. Hence, the WUE data from Expt 2 should be vicwed with catution.

Despite these limitations, it is interesting to note that the WUE values for the container experiment correlated well with those measured in the ficld experiment (Fig. 2), with the cxception of genotype ICGV86843, which had the lowest WUE in Expt 1 but not in Expt 2. The WUE values for this genotype were remarkably low in Expt $\mid$ becaluse of poor plant growth in the containcrs. The reasons for the discrepancy between the performance of this genotype in the contaliner and in the field experiments are not ciear. When this genotype was excluded, however, there was a significant positive correlation $(r=0: 95$, $P<0.01$ ) between the WUEs as measured in containers and in field experiments.

A close correlation between carbon isotope discrimination measured for groundnut genotypes grown in pots and those grown as part of a ficld stand has been shown recently by Wright et al. (1994). A similar consistency in WUE measurenents at the whole plant and canopy level has also been shown in studies of $\mathrm{C}_{3}$ and $\mathrm{C}_{4}$ species (Downes 1969).

\section{REFERENCES}

BrigGS, L. J. \& ShaNTz, H. L. (1913). Water requirements of plants. II. A review of literature. US Department of Agriculture. Plan Industries Bulletin 285, 1-9.

Briggs, L. J. \& SHANTZ, H. L. (1914). Relative water requirement of plants. Journal of Agricultural Research 3 , $1-63$.

De WIT, C. T. (1958). Transpiration and crop yields. Versiagen Land Boursk. Onderzoek 64.6. Wageningen, The Netherlands: Institute of Biological and Chemical Research on Field Crops and Herbage.

DOWNES, R. W. (1969). Differences in transpiration rates between tropical and temperate grasses under controlled conditions. Planta 88, 261-273.
FARQUHAR, G. D. \& Richards, R. A. (1984). Isotopic composition of plant carbon correlates with water-use efficiency of wheat genotypes. Australian Journal of Plant Physiology 11, 539-552.

FArquhar, G. D., EHLERINGer, J. R. \& Hubick, K. T. (1989). Carbon isotope discrimination and photosynthesis. Annual Reviow of Plant Physiology and Molecular Biology 40, 503-537.

Fischer, R. A. \& TuRner, N. C. (1978). Plant productivity in the arid and semiarid zones. Ammal Review of Plant Physiology 29, 277-317.

GibBons, R. W. (1980). The ICRISAT Groundnut Program. In Proceedings of the International Workshop on Ground- 
nut, pp. 12-16. Pntancheru, India: International Crop Research Institute for the Semi-Arid Tropics (ICRISAT).

Hubick, K. T. \& FArquhar, G. D. (1987). Carbon isotope discrimination - sclecting for water use efficiency. Australitan Cotton Grower, 8, 66-68.

Huaick, K. T., Farquilar, G. D. \& Silorter, R. (1986) Correlation between witer-use efficiency and carbon isotope discrimination in diverse peinut (Arachis) germplasm. Australium Joumal of Plant Physiology 13, 803-816.

JoNEs, H. G. (1983). Plants and Microcilinate: A Quantituive Approach to Enviromental Plant Physiology. Cambridge: Cambridge University Press.

KeTRING, D. L. (1984). Root diversity among peanut genotypes. Crop Science 24, 229-232.

MARTIN, B. \& THORSTENSON, Y. R. (1988). Stable carbon isotope composition $\left(\delta^{13} \mathrm{C}\right)$, water use efficiency, and biomass productivity of Lycopersicon esculenttm, Lycopersicon pennellii and the $\mathrm{F}_{1}$ hybrid. Plane Physiology 88, 213-217.

Nageswara Rad, R. C., Wil.tiams, J. H. WAdia, K. D. R.,

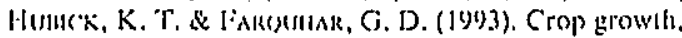
walcr-use elliciency and carbon isolope discrimination in groundnut (Arachis hypugesea L) genotypes under end of season drought conditions. Annals' of Applied Biology 122 , 357-367.

RAVISHANKAR, H. M. (1988). Wuter USe efficiency (IVUE) and gas exchamge characteristics in selected $\dot{C}_{0}$ and $C_{4}$ species - an asiscrssment miler similar water-limited conditions. MSc thesis, Universily of Agricultural Sciences, Bangalore.
RITCHLE, J. T. (1973). Influence of soil water status and metcorological conditions on evaporation from a corn canopy. Agronomy Journal 65, 893-897.

SHASHIKUMAR, M. R. (1983). Field WUE in genotypes of cowipea. MSc thesis, University of Agricultural Sciences, Bangalore.

TANNER, C. B. \& Sinclair, T. R. (1983). Eflicient water usc crop in production: rescarch or re-scarch. In Limitations to Efficien Water Use in Crop Production (Eds H. M. Tayior, W. R. Jordan \& T. R. Sinclair), pp. 1-27. Madjson, USA: American Socicty of Agronomy.

teare, I. D., Kanemasu, E. T., Powers, W. L. \& Jacods, H. S. (1973). Water-use efficiency and its relation to crop canopy arca, stomatal regulation, and root distribution. Agronomy Journal 65, 207-211.

TURNER, N. C. (1986). Crop water deficits: a decade of progress. Advantes in Agronomy 39, 1-51.

UMA, S. (1987). Transpiration quoticn (TQ) and water use efficiency in different $C_{3}$ and $C_{4}$ species and is relationship with biomasss and prodtctivity under moisture stress (monditims. MSc thesis, University of Agricultural Sciences, Bisingillore.

Wricit', G. C., Humick, K. T. \& Fatkquitak, G. D. (1988). Discrimination in carbon isolopes of leaves correlates with water-use efficiency of field-grown peinut cultivars. Australiant Journal of Plant Physiology 15, 815-825.

Wright, G. C., NAgeswara RaO, R. C. \& FArquhar, G. D. (1994). Water-use efficiency and carbon isotope discrimination in peanut under water deficit conditions. Crop Science 34, 92-97. 